\title{
FARMERS' SUBSISTENCE IN INDONESIAN RICE FARMING
}

\author{
Anisa Dwi Utami ${ }^{1}$, and Harianto ${ }^{2}$ \\ 1,2)Department of Agribusiness, Faculty of Economics and Management, IPB University \\ Jl. Kamper Wing 4 Level 5 Kampus IPB Darmaga. Indonesia \\ e-mail: 1)anisadwiutami@apps.ipb.ac.id
}

(Received December 18, 2020/Revised January 29, 2021/Accepted April 1, 2021)

\begin{abstract}
Along with the importance of the rice industry in the agricultural sector and rural development in Indonesia, it arguably requires the understanding of whether rice farmers have been experiencing changes in their agricultural practices. Within the existing literature, it is commonly found that most farmers in developing countries are characterized as subsistence farmers. This paper aims to explore what factors affecting the degree of farmers' subsistence in the Indonesian rice industry. To this end, this study employed regression analysis using data from the national agricultural survey in 2014. The empirical results find that both the characteristics of farm households and rice on-farm characteristics have statistically significant effects on the farmers' decision whether to commercialize or become subsistence. In addition, the farm gate price is also found to have a statistically significant effect, but the effect is found to be relatively small. In general, this study suggests that subsistence farming in the Indonesian rice industry is still significant though many literatures have emphasized the existence of structural change in the agricultural system in Indonesia.
\end{abstract}

Keywords: agricultural system, farm households, on-farm characteristics, regression

\begin{abstract}
ABSTRAK
Sejalan dengan pentingnya posisi industri beras di sektor pertanian dan pembangunan pedesaan di Indonesia, diperlukan pemahaman tentang sejauhmana petani padi mengalami perubahan dalam praktik pertaniannya. Sebagaimana dikemukakan dalam beberapa studi literatur, secara umum petani di negara berkembang cenderung bersifat subsisten. Studi ini bertujuan untuk mengeksplorasi faktor-faktor yang mempengaruhi tingkat subsistensi petani padi di Indonesia. Untuk menjawab tujuan tersebut, penelitian ini menggunakan analisis regresi dengan data survei pertanian nasional tahun 2014. Hasil empiris menunjukkan bahwa baik karakteristik rumahtangga petani maupun karakteristik usahatani padi memiliki pengaruh yang signifikan secara statistik terhadap keputusan petani apakah akan mengkomersialkan atau menjadi subsisten. Adapun harga di tingkat petani juga memiliki pengaruh yang signifikan secara statistik, tetapi efeknya relatif kecil. Secara umum, studi ini menunjukkan bahwa pertanian subsisten dalam industri beras di Indonesia masih signifikan meskipun banyak literatur yang menekankan adanya perubahan struktural dalam sistem pertanian di Indonesia.
\end{abstract}

Kata kunci: karakteristik usahatani, rumah tangga petani, regresi, sistem pertanian

\section{INTRODUCTION}

Within the existing agricultural literatures, Asian food production system can be categorized as subsistence and commercial system. Not with standing the changing socioeconomic conditions, such as increasing economic growth and urbanization, the degree of agricultural commercialization has been increasing in many developing countries, particularly in Asia. Agricultural commercialization means a shifting production orientation from producing food to serve farmer's own household consumption into profit maximization orientation. Therefore, the decision in the product choice and input use are toward the profitability consideration. 
Rice is the staple food for most households in Indonesia. The importance of rice in household consumption can be seen from the effect of changes in rice prices on the demand for rice and other non-rice staple food in rural households. Allo et al. (2018) shows that when rice prices increase, instead of causing demand for non-rice staple foods increase but it decreases. Households seem to be prioritizing the fulfillment of rice before fulfilling other food ingredients. The study also shows that the own price elasticity of rice demand in rural areas is less elastic compared to the demand for rice in urban areas. Household farmers in rural areas do not only act as consumers of rice but most are also producers. How rice farmers react to changing rice prices will depend on the objectives of farmers in farming. Subsistence farmers will have a different decision compared to farmers that are entirely serving the market. Increasing rice production because of rising price does not necessarily change to an increase in rice supply in the market if the increase is not sold but to increase farmer household consumption. Subsistence behavior of rice farmers will have an impact on national food security.

Rice farming in Indonesia can be categorized as a small farmer. Based on the 2014 Food Crop Survey (Survei Tanaman Pangan) of the Indonesia Statistics (BPS), the average area of cultivated rice is 0.46 hectares per household. The small size of land makes income from rice farming insufficient to cover all household expenses, so farmers seek other sources of income outside of rice farming, such as hired labor in off-farm and non-farm activities. The limited land-owned and limited capital employed makes rice farming not necessarily fully able to serve the market.

The subsistence nature in rice farming makes the allocation of farming resources not fully following the pattern of resource allocation in agriculture that is fully commercially motivated and oriented to serve the market. This subsistence character in rice farming is important to understand especially in the context of government policies and efforts to strengthen small land farmers in the face of environmental changes (Pauw, 2013), and conservation efforts (Southgate et al, 2009). Subsistence farming is often associated with low yield productivity due to lower adoption of better technology. Farming that has subsistence characteristics on a certain degree or semi subsistence is also considered to be able to avoid the influence of policies that are considered detrimental, because farming is not fully exposed to market changes that occur (Pennesi, 2015).

This research is intended to find out the factors that can explain the degree of subsistence of rice farming households in Indonesia. Subsistence is viewed from the output utilization and not from the source of farm inputs. Output subsistence occurs when the product produced in part or in whole is allocated for the needs of the farmer's own household consumption. Whereas from the input side, subsistence can be identified from the utilization of production inputs originating from own households. either in part or in whole, and not obtained from purchases on the market. The novelty of this study lies in the model built which can reveal that the subsistence character of rice farming can change and be influenced by internal and external factors of farm household. Subsistence behavior still exists in rice farming with varying degrees between households. Knowledge of the factors that influence farmers' subsistence is beneficial for efforts to improve the efficiency and productivity of rice farming.

\section{METHODS}

This study uses data from national agricultural survey conducted by Indonesia Statistics (BPS) in 2014 namely Survei Tanaman Pangan (STP 2014) covering 87.330 rice farmers in Indonesia. This survey is conducted regularly every three years according to the government regulation which targets on the farm households in Indonesia for several strategic agricultural commodities. 
Observations with missing data are excluded from the dataset. Therefore, this study employs 62.136 respondents from the survey.

As this study aims to explore what factors affecting the degree of subsistence of the rice farmers in Indonesia, the dependent variable is represented by the percentage of the yield (production) for the households' consumption. This implies that the higher value means the higher degree of becoming subsistence (or the lower degree of commercialization-vice versa). Accordingly, the degree of subsistence is linearly modeled as a function of price, the characteristics of farmers and on-farm business represented by the equation 1.

$Y_{i}=\beta_{0}+\beta_{p i} P_{f i}+\ldots+\beta_{k i} Z_{k i}+\varepsilon_{i}$

where $Y_{i}$ is the percentage of rice consumed as the dependent variable. $P_{\mathrm{i}}$ represents the farm gate price, and $\mathrm{Z}$ is the set of independent variables representing the characteristics of farmers involving gender, education, age, participation on training and farmer group, and the on-farm business including farm size, technology, equipment, input uses, insurance, etc. (see Table 1 for the details). In addition, to

Table 1. Dependent and Independent Variables for the Regression

\begin{tabular}{|c|c|c|}
\hline Variable & Description & $\begin{array}{c}\text { Expected Sign of Parameters } \\
\text { (The Hypothesis) }\end{array}$ \\
\hline \multicolumn{3}{|l|}{ Dependent } \\
\hline $\begin{array}{l}\text { Households' } \\
\text { consumption }\end{array}$ & $\begin{array}{l}\text { The Share of Households' consumption from one-year } \\
\text { production in percentage }(0-100 \%)\end{array}$ & \\
\hline \multicolumn{3}{|c|}{1} \\
\hline Price & Farm gate price in thousand IDR per kilogram & - \\
\hline Gender & $\begin{array}{l}1=\text { Female } \\
0=\text { Male }\end{array}$ & $+/-$ \\
\hline Age & Year & - \\
\hline \multirow[t]{9}{*}{ Education } & Categorical 1-8 & - \\
\hline & $1=$ unschooled & \\
\hline & $2=$ primary school & \\
\hline & $3=$ junior high school & \\
\hline & $4=$ senior high school & \\
\hline & $5=\mathrm{D} 1 / \mathrm{D} 2$ & \\
\hline & $6=\mathrm{D} 3$ & \\
\hline & $7=$ bachelor & \\
\hline & $8=$ master $/$ doctor & \\
\hline \multirow[t]{2}{*}{ Training } & $1=$ participate & - \\
\hline & $0=$ not participate & \\
\hline \multirow[t]{2}{*}{ Member } & $1=$ member of farmer group $/$ association & - \\
\hline & $0=$ non-member & \\
\hline \multirow[t]{2}{*}{ Own_house } & $1=$ have own house & + \\
\hline & $0=$ otherwise (e.g. renting house) & \\
\hline Size_house & $\mathrm{m}^{2}$ & - \\
\hline \multirow[t]{3}{*}{ Type_house } & Categorical (1-6) & + \\
\hline & 1 = highest quality & \\
\hline & $6=$ lowest quality & \\
\hline \multirow[t]{2}{*}{ Own_farm } & $1=$ have own farm & + \\
\hline & $0=$ otherwise (e.g. renting farm) & \\
\hline Farm size & $\mathrm{m}^{2}$ & - \\
\hline \multirow[t]{2}{*}{ Irrigation } & $1=$ using irrigation technology & - \\
\hline & $0=$ otherwise & \\
\hline \multirow[t]{2}{*}{ Monoculture } & $1=$ monoculture & - \\
\hline & $0=$ multiculture & \\
\hline \multirow[t]{2}{*}{ Buying_seed } & $1=$ buying the seed & - \\
\hline & $0=$ not buying the seed & \\
\hline Farm own financing & $\begin{array}{l}\text { Percentage of the source of financing for farming } \\
\text { activities coming from own capital }(0-100 \%)\end{array}$ & + \\
\hline \multirow[t]{2}{*}{ Rent_equipment } & $1=$ renting the farming equipment & - \\
\hline & $0=$ not renting the farming equipment & \\
\hline \multirow[t]{2}{*}{ Farm_Insurance } & $1=$ have $a$ farm insurance account & - \\
\hline & $0=$ not have $\mathrm{a}$ farm insurance account & \\
\hline \multirow[t]{3}{*}{ Regions } & Regions in Indonesia & $+/-$ \\
\hline & 1 = Java & \\
\hline & $0=$ otherwise & \\
\hline
\end{tabular}


cover the regional heterogeneity a categorical variable representing regions in Indonesia (mainly based on the island) is included in the model. The relationships between the dependent and independent variables are estimated by using linear regression model with robust standard error to deal with the problem of heteroskedasticity. The details of the dependent and independent variables are presented in the Table 1.

\section{RESULT AND DISCUSSION}

Within the general economic framework, firm is usually treated as the producer and households play as consumer of a product as separate agencies. Firms are supposed to produce and sell their products with the aim of maximizing profits, while households supply labor and other resources for hire and use the proceeds to purchase the goods and services they desire. Meanwhile, in the case of agricultural system especially in many developing countries, farmer can play both roles as producer and consumer. In other words, both roles are combined in the same decision-making households.

The degree of subsistence farming behavior is measured by whether the farmers decide to save their rice production for their own consumption as depicted by the Figure 1. As shown in the Figure 1, 18,92\% of the respondents consume totally (100\%) from their rice production. In contrast, there are only 5,23 \% respondents who totally commercialize their rice production $(0 \%)$. Meanwhile, as mentioned in the Table 2, the average level of the households' consumption is at $53,57 \%$ from the one-year production. Similarly, there are $57 \%$ of the respondents who use at least $50 \%$ of their production for the households' consumption. This finding suggests that the degree of subsistence farming in Indonesian rice sector is still high.

According to the estimated regression model, the findings suggest that most of variables have significant effect to the dependent variable. The exception is only found in the case of gender which is not statistically significant at any level. Meanwhile, regarding the sign of estimated

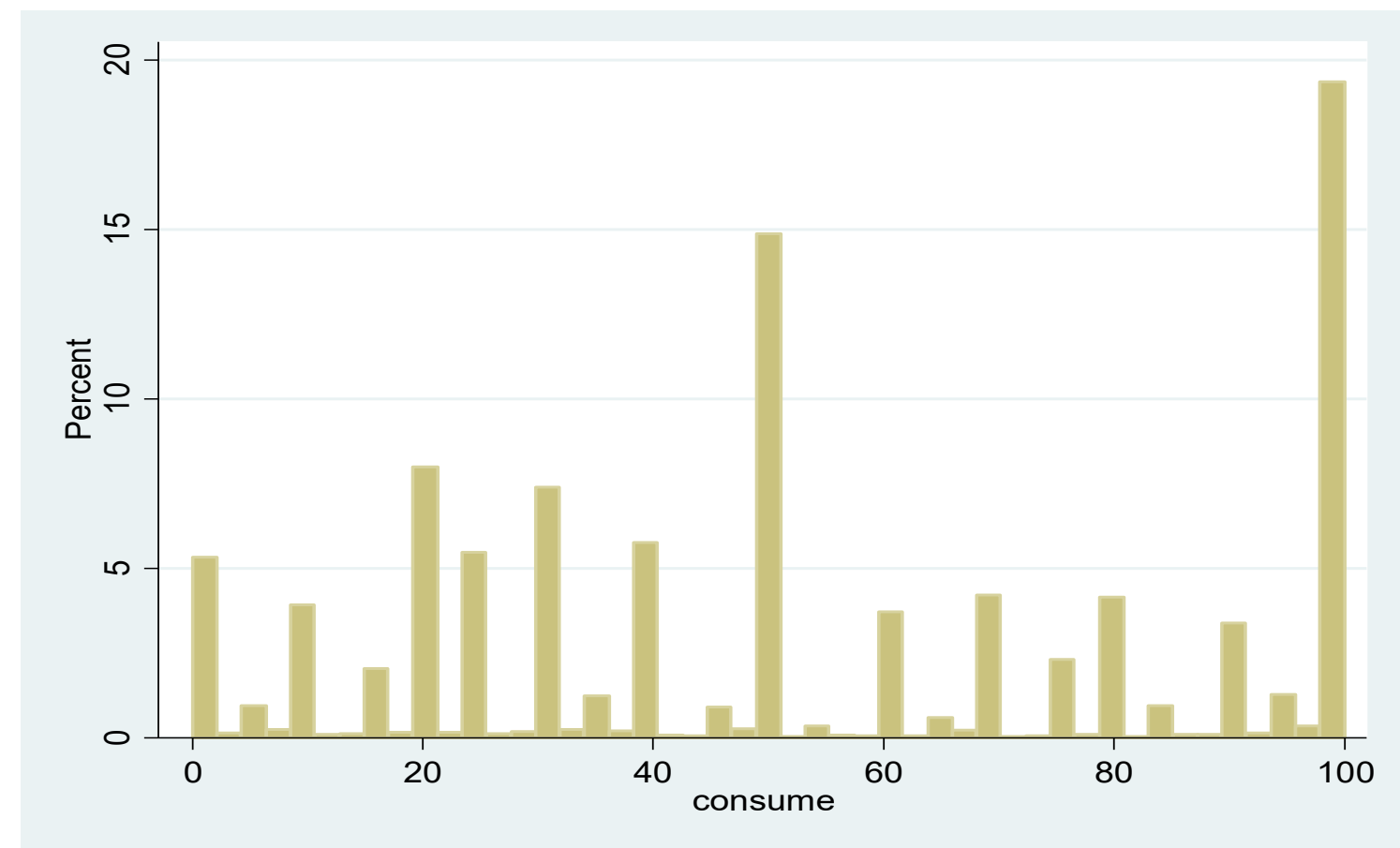

Figure 1. The Percentage of Respondents According to the Percentage of Rice Consumed from the Rice Production 
Table 2. Summary Statistics of the Variables

\begin{tabular}{lrrrr}
\hline \multicolumn{1}{c}{ Variable } & Mean & $\begin{array}{c}\text { Standard } \\
\text { Deviation }\end{array}$ & Minimum & Maximum \\
\hline Households' consumption & 53,57 & 32,47 & 0 & 100 \\
Price & 3,96 & 1,12 & 2,5 & 23,08 \\
Age & 49,92 & 12 & 11 & 99 \\
Gender & 0,89 & 0,31 & 0 & 1 \\
Education & 2,29 & 1,21 & 1 & 8 \\
Training & 0,13 & 0,33 & 0 & 1 \\
Member & 0,56 & 0,49 & 0 & 1 \\
Own house & 0,96 & 0,20 & 0 & 1 \\
Size_house & 81,82 & 131,08 & 1 & 7.500 \\
Type_house & 2,71 & 1,49 & 1 & 6 \\
Own_farm & 0,71 & 0,45 & 0 & 1 \\
Farm size & $4.679,04$ & $5.355,86$ & 56 & 400.000 \\
Irrigation & 0,55 & 0,49 & 0 & 1 \\
Monoculture & 0,98 & 0,10 & 0 & 1 \\
Buying_seed & 0,54 & 0,50 & 0 & 1 \\
Farm_own financing & 94,15 & 15,96 & 0 & 100 \\
Rent_equipment & 0,65 & 0,47 & 0 & 1 \\
Farm insurance & 0,00 & 0,04 & 0 & 1 \\
Region & 2,46 & 1,42 & 1 & 7 \\
\hline
\end{tabular}

coefficient, the findings also support the hypothesis in general. Regarding the robustness of the estimated regression model, we test whether the model can produce best linear unbiased estimation by checking the presence of multicollinearity and autocorrelation of the error term. Since this research already use robust standard error in the model specification, then it can deal with the problem of heteroskedasticity. By referring to the value of variance inflation factor (VIF) which is found at 1.07, thus it can be concluded that the estimated regression model does not have problem of multicollinearity. Meanwhile, the residuals are also found to be normally distributed and have no autocorrelation.

\section{THE EFFECT OF PRICE}

In the economics framework, price can play a role as a driver in the people's decision. In this case, price can be a signal whether it is more profitable for rice farmers to commercialize their production, or it is better to save their production and use it for their households' consumption. Therefore, following the common economic sense, and assuming farmer as a rational producer, it is expected that higher prices will lead to the higher degree of commercialization. Correspondently, it also implies that when the farmers get a low price then they will likely save their production for their own households' consumption. According to the findings of the regression model, it is confirmed that price is statistically significant in affecting the farmer's decision with the expected correlation between price and the degree of subsistence (see Table 3).

However, even though the effect is found to be statistically significant, but according to the magnitude of the estimated coefficient, it is suggested that the effect is relatively small. The estimated coefficient of price is $-0,606$ which means that when the farm gate price is increasing 1.000 IDR then farmers will likely reduce $0,60 \%$ of their rice production for their households' consumption or farmers will sell $0,60 \%$ more of their rice production, on average. As mentioned in the Table 2, the average price is at 3.960 IDR. Therefore, with this magnitude, though price found to be statistically significant, but the effect is relatively small. Price elasticity for subsistence agriculture is only 0,024 . The decision to 
utilize the crop for own consumption is not only influenced by the selling price of the products produced, but also by the expectations of rice prices and transaction costs when rice farming households want to buy rice in the market for consumption (Cadot et al. 2010). The difference in rice prices at the farm level with the price of rice at the consumer level is relatively large. The average price of un-husked paddy at farm level was $3.960 \mathrm{IDR}$. and the average price of rice at the retail level was 7.800 IDR. Considering the situation where most rice farmers are likely a price taker in the market, this leads to the question whether rice industry in Indonesia can provide a profitable source of income for farmers. In other words, the finding suggests that rice farming still plays a role as food supply for farm households' consumption.

\section{THE ROLE OF HOUSEHOLD CHARACTERISTICS}

Farmers' behavior is explored by investigating the farmer characteristics including several demographic variables and the capital ownerships (see Table 1). As presented in Table 3, most explanatory variables represent the farmers' characteristics are found to be statistically significant except gender. Gender aspects in subsistence farming or food security have not received adequate attention (Lang and Barling. 2012). This study shows that gender does not have a significant effect on subsistence levels in rice farming. The heads of male and female households do not have a different tendency to determine the share of production that is intended for selfconsumption.

Table 3. The Results of Regression Analysis

\begin{tabular}{|c|c|c|c|}
\hline \multirow[b]{2}{*}{ Independent Variable } & \multicolumn{3}{|c|}{ Dependent Variable: Households' Consumption } \\
\hline & $\begin{array}{l}\text { Estimated } \\
\text { Coefficient }\end{array}$ & $\begin{array}{c}\text { Robust Standard } \\
\text { Error }\end{array}$ & t-Statistics \\
\hline Constant & 59,032 & 1,851 & $31,89^{* * *}$ \\
\hline Price & $-0,606$ & 0,112 & $-5,39 * * *$ \\
\hline Age & $-0,05$ & 0,112 & $-4,70^{* * *}$ \\
\hline Gender & 0,008 & 0,453 & 0,02 \\
\hline Education & $-0,596$ & 0,110 & $-5,41^{* * *}$ \\
\hline Training & $-2,529$ & 0,373 & $-6,79^{* * *}$ \\
\hline Member & $-2,322$ & 0,286 & $-8,15^{* * *}$ \\
\hline Own house & 1,073 & 0,579 & $1,85^{*}$ \\
\hline Size_house & $-0,001$ & 0,000 & $-2,55^{* *}$ \\
\hline Type_house & 0,802 & 0,089 & $8,96^{* * *}$ \\
\hline Own_farm & 4,572 & 0,273 & $16,71^{* * *}$ \\
\hline Farm size & $-0,002$ & 0,000 & $-10,76^{* * *}$ \\
\hline Irrigation & $-10,236$ & 0,250 & $-40,86^{* * *}$ \\
\hline Monoculture & $-4,365$ & 1,178 & $-3,71^{* * *}$ \\
\hline Buying_seed & $-8,694$ & 0,264 & $-32,89^{* * *}$ \\
\hline Farm_financing & 0,212 & 0,007 & $27,65^{* * *}$ \\
\hline Rent_equipment & $-1,745$ & 0,266 & $-6,56^{* * *}$ \\
\hline Farm insurance & $-5,699$ & 2,621 & $-2,17^{* *}$ \\
\hline Region & $-0,198$ & 1,851 & $-1,75^{*}$ \\
\hline Number of Observations & & & 62.136 \\
\hline F-statistics (11. 62117) & & & 349.10 \\
\hline Prob $>$ F & & & 0.0000 \\
\hline R-square & & & 0,1445 \\
\hline Root MSE & & & 30,037 \\
\hline
\end{tabular}

Notes: *statistically significant at $10 \%$ level of significance.

${ }^{* *}$ statistically significant at $5 \%$ level of significance.

***statistically significant at $1 \%$ level of significance 
Additionally, the dummy variable of own house which implies whether the rice farmers own their house is statistically significant at 10 $\%$ level of significance. Regarding to the sign of the estimated coefficient, the results generally reveal the similar finding as hypothesized. However. regarding the magnitude since most variables are constructed as dummy variables then the coefficient should not be over-interpreted.

As presented in the Table 3, it is confirmed that older farmers tend to become less subsistence. The results of this study are different from the findings of Lekobane and Seleka (2011) who found that older age would increase household participation in subsistence farming. Old farmers in Botswana have lower employment opportunities than young farmers. relying on the results of subsistence farming. Lekobane and Seleka's research shows that farmers who have jobs outside of farming are only 15 percent. This is different in Indonesia where rice farmers generally have other sources of income outside of farming.

Meanwhile, farmers with higher education will likely become less subsistence. This finding is also consistent with the farmers' participation in the training program as well as becoming a member in the farmers group organization tend to become less subsistence, respectively. Participation in extension programs and in farmer groups will facilitate farmers' access to technology that can increase crop productivity (Negash and Swinnen. 2013). Better education also allows farmers to use more time to work outside agriculture. The Rodriguez-Meza et al. (2004) show that low education minimizes the opportunity of farmers to earn income from outside agriculture and farmers are more dedicated to their work for subsistence farming.

Increased production will increase the share of production sold to the market. Furthermore, farmers with higher assets (see the variables of farmers' house) will likely become less subsistence as well. The results of this study are in line with the results obtained by Lekobane and Seleka (2011) which show that farmers who have more livestock assets will be increasingly less likely to seek food crop farming for subsistence needs.

\section{THE ROLE OF FARM CHARACTERISTICS}

Beside affected by the household characteristics, the behavior of subsistence farming is also influenced by the on-farm characteristics. Based on the estimation from the regression model, most of explanatory variables representing the on-farm characteristics are found to be statistically significant. It is found that farmer who owns the farm is likely become more subsistence than farmers who does not. It is consistent with the situation that subsistence farmers own a smaller size of farmland compared to more commercialized farmers. Consistently, the higher farm size will lead to higher degree of commercialization. Holland et al. (2017) states that access to technology and other sources of income outside agriculture makes subsistence farmers rely on production from the land they have for household food security. Khalif and Nur (2013) stated that the small arable land area could be a barrier in increasing productivity and sustainability of food agriculture.

Monoculture rice farms tend to sell their crops to the market, or less subsistence, compared to non-monoculture rice farmers. Monoculture farmers rely more on their paddy yields they sold to buy food and nonfood needs than non-monoculture rice farmers. Monoculture rice farmers are more commercial. and business based on the calculation of risk and profit. while nonmonoculture farmers tend to be risk averse and give priority to meet the household food needs rather than the amount of profit earned. The results of research by Tibesigwa et al. (2014) found that subsistence farmers use crops-livestock mixed farming as a strategy to reduce risk and coping strategies in dealing with changing external conditions.

Rice farming whose land is irrigated and employed seeds from purchases on the market. tends to decrease the degree of 
subsistence. Rice farming that uses equipment from leasing and ensuring its farming also tends to be more commercial in nature and the greater the percentage of yields sold to the market and less for household own consumption. The results of this study are consistent with the opinion of Von Maltitz et al. (2016) which states that increasing commercialization or declining degree of subsistence will occur rapidly if farmers' access to input markets and output markets is increasingly open.

The own farm financing variable has a positive influence on the share of production that is consumed by the household. This result is in accordance with the initial hypotheses, where it is expected that the lesser the access of farmers to the source of financing, the lower the degree of commercialization of rice farming. Due to education and financial literacy are low, farmers in Indonesia generally find it difficult to gain access to formal financing sources (Widhyanto et al. 2018). Tanomchat and Sampattavanija (2018) study in Thailand found that informal money lenders were increasingly accessible to farmers when it was clear the collateral owned by farmers and lenders was familiar with both the family and borrowers' acquaintances. Subsistence farmers in Indonesia relatively experience more difficulties to borrow money from formal and informal lenders compare to commercial farmers.

The results of study also show that rice farming in Java region tend to be more commercial than farming outside Java regions. Java is known as the rice producing center for Indonesia. Rice farmers in Java also have better access to output and input markets and funding sources compared to farmers outside Java. These results reinforce the argument for the need for better market access to reduce the degree of subsistence of rice farming in Indonesia.

\section{CONCLUSION}

1. As emphasized in many existing literatures, the importance of transformation of agricultural system from subsistence towards commercialization requires the understanding of underlying characteristics of the subsistence behavior of the farmers. Despite the existence of a growing economic growth, the presence of subsistence agriculture in rice farming in Indonesia cannot be neglected. Considering rice as the main staple food for most Indonesian people, the rice consumption will not be avoided especially for the low-income people. In this context, thus the degree of subsistence will be higher for small farmers. Furthermore, farmers' decisions to become subsistence or commercialize are affected by the characteristics of household and on farm business.

2. The household characteristics that have a positive effect on reducing the degree of subsistence on rice farming are the education and training received by farmers and the number of household members. The external aspect of the household that has a positive effect on the commercialization of rice farming is price and market access. The price of rice received by farmers determines the share of rice production that is used for farmer household own consumption. The higher the price received by farmers, the greater the willingness of farmers to abandon their subsistence attitude. The subsistence level of rice farmers is also influenced by farmers' access to input markets and output markets. The better the farmers' access to the inputs and output market are the lower the degree of rice farming subsistence. 


\section{REFERENCES}

Allo AG. Satiawan E. and Arsyad L. (2018). The Impact of Rising Food Prices on Farmers' Welfare in Indonesia. Journal of Indonesian Economy and Business 33(3): 193-215.

Cadot O. Dutoit L. and Olarreaga M. (2010). Barriers to Exit from Subsistence Agriculture. In Porto G. and Hoekman B. (Eds.). Trade Adjustment Costs in Developing Countries. London: Center for Economic Policy Research. and Washington. DC: World Bank. pp. 89100.

Holland MB. Shamer SZ. Imbach P. Zamora JC. Moreno CM. Hidalgo EJL. .... and Harvey CA. (2017). Mapping Adaptive Capacity and Smallholder Agriculture: Applying Expert Knowledge at The Landscape Scale. Climatic Change 141:139-153. doi: 10.1007/s10584-016$1810-2$

Khalif A. and Nur A. (2013). The African Farmer and The Challenge of Food Security In Africa. Development 56(2): 257-265. doi:10.1057/dev.2013.25

Lang T. and Barling D. (2012). Food Security and Food Sustainability: Reformulating the Debate. Geogr J 178:313-326. doi: 10.1111/j.1475-4959.2012.00480.x

Lekobane KR. and Seleka TB. (2011). Do Public Transfers Discourage Farmer Participation in Subsistence Crop Production? Empirical Evidence from Botswana. IDEAS Working Paper Series from RePEc; St. Louis.

Negash M. and Swinnen JFM. (2013). Biofuels and Food Security: Micro-Evidence from Ethiopia. Energy Policy 61:963-976. doi: 10.1016/j.enpol.2013.06.031

Pauw P. (2013). The Role of Perception in Subsistence Farmer Adaptation in Africa: Enriching the Climate Finance Debate. International Journal of Climate Change Strategies and Management 5(3): 267-284. doi: 10.1108/IJCCSM-03-2012-0014
Pennesi K. (2015). Constructing 'Farmer' And 'State' Identities in Moral Discourses about Semi-Subsistence Agriculture in North-east Brazil. J. Lat. Amer. Stud. 47:781-809.

doi: 10.1017/S0022216X1500084X

Rodriguez-Meza J. Southgate D. and Gonsalez-Vega C. (2004). Rural Poverty. Household Responses to Shocks and Agricultural Land Use: Panel Results For El Salvador. Environment and Development Economics 9: 225-239. doi: 10.1017/S1355770X03001244.

Southgate D. Rogriguez F. and Haab T. (2009). Payments For Sustainability: A Case Study on Subsistence Farming in Ecuador. Harvard International Review 31(2): 54-56.

Tibesigwa B. Visser M. and Turpie J. (2015). The Impact Of Climate Change On Net Revenue And Food Adequacy Of Subsistence Farming Households In South Africa. Environment and Development Economics 20(3): 327-353. DOI:10.1017/S1355770X1400054.

Tanomchat W. and Sampattavanija S. (2018). Dependence Of Informal Interest Rates and Level Of Lenders' Influence In The Informal Loan Market In Thailand. International Advances in Economic Research 24 (1): 47-63. doi:10.1007/s11294018-9672-1

Von Maltitz GP. Gasparatos A. Fabricius C. Morris A. and Willis KJ. (2016). Jatropha Cultivation in Malawi and Mozambique: Impact on Ecosystem Services, Local Human Well-Being. and Poverty Alleviation. Ecology and Society 21(3):3. http://dx.doi.org/10.5751/ES-08554$\underline{210303}$

Widhiyanto I. Nuryartono N. Harianto. and Siregar H. (2018). The Analysis of Farmers' Financial Literacy and Its' Impact on Microcredit Accessibility with Interest Subsidy on Agricultural Sector. International Journal of Economics and Financial Issues. 8(3): 148-159. 